\title{
KRIMINĀLTIESĪBU NORMU SAPROTAMĪBA UN SISTĒMISKUMS
}

\section{COMPREHENSIBILITY AND SYSTEMICISM OF THE CRIMINAL LAW PROVISIONS}

\section{Evija Vīnkalna, $M g$. soc.}

Latvijas Universitātes Juridiskās fakultātes

Krimināltiesisko zinātṇu katedras lektore

\section{Summary}

The Section 90 of the Constitution (Satversme) of the Republic of Latvia provides that everybody has the right to know his/her rights, and it includes public availability, predictability, clarity and understandability of legal provisions.

Section 90 of the Constitution has the essential meaning in the context of criminal law, because in conjunction with Section 92 of the Constitution it particularly guarantees rights to clarity and predictability of criminal law provisions, especially speaking about dispositions of sections in the Special Part of the Criminal Law. At the same time, clarity and understandability of criminal law provisions are no less important in the context of imposing a punishment.

The article is dedicated to predictability, clarity and understandability of the criminal law provisions in the scope of theoretical and practical assessment in case of determining a punishment.

Atslēgvārdi: Krimināllikums, norma, saprotamība, sistēmiskums, soda noteikšana

Keywords: Criminal Law, norm, provision, comprehensibility, systematicality, determination of punishment

Raksta mērḳis ir pievērsties krimināltiesību normu skaidrības, saprotamības un sistēmiskuma prasībai saistībā ar soda noteikšanas jautājumiem.

Latvijas Republikas Satversmes"1 90. pants nosaka: "Ikvienam ir tiesības zināt savas tiesības," no tā izriet vairāki nosacījumi. Pirmkārt, tiesību normām jābūt publiski pieejamām, nosakot valstij pienākumu iepriekš publicēt visus normatīvos aktus, lai tās jurisdikcijā esošās privātpersonas varētu objektīvi zināt un paredzēt, kādas normas tiks piemērotas noteiktai tiesiskai attiecībai. ${ }^{2}$ Otrkārt, tiesību normām jābūt paredzamām, skaidrām un saprotamām - tas nozīmē, ka normas

${ }^{1}$ Latvijas Republikas Satversme: LV likums. Pieņemts 15.02.1922. [21.02.2019. red.].

2 Rudevskis J. 90. Ikvienam ir tiesības zināt savas tiesības. Grām.: Latvijas Republikas Satversmes komentāri. VIII nodaḷa. Cilvēka pamattiesības. Autoru kolektīvs prof. R. Baloža zinātniskā vadībā. Rīga: Latvijas Vēstnesis, 2011, 66. lpp. 
saturam jābūt tādam, lai privātpersona zinātu, kādas tiesiskās sekas rodas no noteiktiem juridiskiem faktiem vai noteiktas rīcības (darbības vai bezdarbības). ${ }^{3}$

Latvijas Republikas Satversmes tiesa vairākkārt uzsvērusi, ka Latvijas Republikas Satversmes 90. pants prasa, lai tiesību normas būtu ne tikai publiski pieejamas, bet arī pietiekami skaidras un saprotamas - tas ir formulēts pietiekami precīzi, ${ }^{4}$ un tie ir arī tiesību normu kvalitātes kritēriji (ikvienai tiesību normai jābūt pieejamai, pietiekami skaidrai un paredzamai). ${ }^{5}$ Tiesību normas skaidrība un paredzamība ir vērtējama, pamatojoties uz šĩs normas interpretāciju - ja ar tās paṇēmienu palīdzību nav iespējams noskaidrot normas patieso jēgu, tad norma atzīstama par neskaidru. ${ }^{6}$ Tiesību normas paredzamības prasība nenozīmē, ka tiesas nedrīkstētu precizēt šīs normas saturu judikatūras cel̦āi, ${ }^{7}$ arī doktrīnā atzītais palīdz noskaidrot normas saturu.

Pamatots ir atzinums, ka kriminālatbildība kā smagākais juridiskās atbildības veids var būtiski ietekmēt personas dzīvi arī pēc kriminālsoda izciešanas, tādēl kriminālatbildību paredzošām normām jābūt saturiski noteiktākām nekā citu tiesību nozaru normām, ${ }^{8}$ tas nozìmē, ka Latvijas Republikas Satversmes 90. pantam ir īpaša nozīme krimināltiesību kontekstā, un kopsakarā ar Latvijas Republikas Satversmes 92. pantu ${ }^{9}$ tas sevišḳi garantē tiesības uz krimināltiesību normu skaidrību un paredzamību. ${ }^{10}$

Cilvēka tiesību un pamatbrīvību aizsardzības konvencijas 7. panta pirmajā daḷā noteikts: "Nevienu nedrīkst apsūdzēt kriminālnoziegumā tāda nodarījuma vai nolaidỉbas dēḷ, kas, saskaṇā ar izdarīšanas brīdī spēkā bijušo valsts iekšējo likumdošanu vai starptautiskajām tiesībām, nebija kriminālnoziegums. Tāpat nedrīkst piespriest smagāku sodu nekā tas, kas bija jāpiemēro nozieguma izdarīšanas brīdī."11

Likumības princips krimināltiesībās nozīmē, ka nodarījuma noziedzīgumu, sodāmību un citas krimināltiesiskās sekas nosaka tikai Krimināllikums, ${ }^{12}$ un viens no šì principa būtiskiem aspektiem ir Krimināllikuma normu noteiktības, skaidrības un saprotamības prasība. Saskaṇā ar Krimināllikuma ${ }^{13}$ 1. pantā noteikto personu var saukt pie kriminālatbildības un sodìt tikai saskaṇā ar Krimināllikumu. Arī ārvalstu krimināllikumi satur krimināltiesību normu noteiktības

\footnotetext{
3 Rudevskis J. 2011, 69. lpp.

${ }^{4}$ Satversmes tiesas 20.12.2006. spriedums lietā Nr. 2006-12-01, 16., 23. p.; Satversmes tiesas 25.10.2004. spriedums lietā Nr. 2004-03-01, 9.2. p.; Satversmes tiesas 30.03.2011. spriedums lietā Nr. 2010-60-01, 15.2. p. Pieejams: www.satv.tiesa.gov.lv [aplūkots 21.02.2019.].

${ }^{5}$ Sk., piemēram: Satversmes tiesas 21.02.2019. spriedums lietā Nr. 2018-10-0103, 13.1. p. Pieejams: www. satv.tiesa.gov.lv [aplūkots 22.03.2019.].

${ }^{6}$ Satversmes tiesas 30.03.2011. spriedums lietā Nr. 2010-60-01, 15.2. p. Pieejams: www.satv.tiesa.gov.lv [aplūkots 21.02.2019.].

7 Rudevskis J. 2011, 70. lpp.

${ }^{8}$ Satversmes tiesas 21.02.2019. spriedums lietā Nr. 2018-10-0103, 13.2. p. Pieejams: www.satv.tiesa.gov.lv [aplūkots 22.03.2019.].

${ }^{9}$ Latvijas Republikas Satversmes 92. panta pirmajos divos teikumos noteikts: "Ikviens var aizstāvēt savas tiesības un likumiskās intereses taisnīgā tiesā. Ikviens uzskatāms par nevainīgu, iekams viņa vaina nav atzīta saskaņā ar likumu."

10 Rudevskis J. 2011, 70. lpp.

11 Cilvēka tiesību un pamatbrīvību aizsardzības konvencija. Parakstīta Romā 04.11.1950. [27.02.2019. red.].

12 Sk., piemēram: Krastiņš U., Liholaja V., Niedre A. Krimināltiesības. Vispārīgā daḷa. Trešais papildinātais izdevums. Zinātniskais redaktors prof. U. Krastiņš. Rīga: Tiesu namu aǵentūra, 2008, 21. lpp.

13 Krimināllikums: LV likums. Pieņemts 17.06.1998. [27.02.2019. red.].
} 
nepieciešamības prasību. Tā Austrijas kriminālkodeksa ${ }^{14}$ 1. paragrāfa pirmajā daḷā paredzēts, ka sods vai preventīvais līdzeklis var tikt noteikts tikai par tādu nodarījumu, tieši par kuru likumdevējs ir noteicis soda piedraudējumu un kurš tā izdarīšanas laikā jau bija kriminālsodāms. Norāde uz soda noteiktību un skaidrību iestrādāta Sanmarīno kriminālkodeksa 1. panta pirmajā daḷā, kur norādīts, ka neviena persona nedrīkst tikt pakḷauta sodam, kas nav izteikts noteikti un skaidri, tāpat arī tādam sodam, kas nav paredzēts likumā. ${ }^{15}$

Krimināltiesību normu skaidrībai un saprotamībai ir būtiska nozīme attiecībā uz Krimināllikuma Sevišķās daḷas pantu dispozīcijām, bet ne mazāka nozīme ir tām krimināltiesību normām, kas attiecināmas uz soda noteikšanas jautājumiem.

Krimināllikuma 46. panta otrajā daḷā paredzēts, ka, nosakot soda mēru, n̦em vērā atbildību mīkstinošos un pastiprinošos apstākḷus. Pie tam atbildību mīkstinošajiem un pastiprinošajiem apstāḳ̣iem var būt nozīme arī, piemēram, nosakot vieglāku sodu nekā likumā paredzētais sods (Krimināllikuma 49. pants). Krimināllikuma 47. panta pirmās daḷas trešajā punktā noteikts viens no atbildību mīkstinošajiem apstākḷiem: "Vainīgais labprātīgi atlīdzinājis cietušajam ar noziedzīgo nodarījumu radīto kaitējumu vai novērsis radīto kaitējumu." Lai minēto apstākli varētu atzīt, nepieciešams konstatēt noziedzīgo nodarījumu izdarījušās personas labprātīgu rīcību ${ }^{16}$ un to, ka no šìs personas puses radìtais kaitējums ir atlīdzināts vai novērsts pilnā apmērā. ${ }^{17}$ Latvijas Republikas Augstākā tiesa atzinusi, ka no Krimināllikuma 47. panta pirmās daḷas 3. punkta izriet likumdevēja norāde uz jau notikušu faktu (tas ir - kaitējums ir atlīdzināts pilnā mērā). ${ }^{18}$ Lìdzīgi uzsvērts arī apkopojumā "Tiesu prakse krimināllietās par noziedzīgiem nodarījumiem pret tikumību un dzimumneaizskaramību, kas izdarīti ar nepilngadīgo", Krimināllikuma 47. panta pirmajā daḷā norādīto apstākḷu tvērumā neatzīstot daḷēju zaudējumu atlīdzināšanu. ${ }^{19}$

Vienlaikus jānorāda, ka iepriekš minētais ne vienmēr tiek viennozīmīgi vērtēts, tajā skaitā praksē, kur saskaṇā ar Krimināllikuma 47. panta pirmās daḷas 3. punktu atzìta arī daḷēja ar noziedzīgo nodarījumu radītā kaitējuma atlīdzināšana. ${ }^{20}$

${ }^{14}$ Austrijas kriminālkodekss. Grām.: Krastiņš U., Liholaja V. Salīdzināmās krimināltiesības. Latvija, Austrija, Šveice, Vācija. Rīga: Tiesu namu aǵentūra, 2006, 240.-336. lpp.; Criminal Code of the Republic of Austria [Austrijas kriminālkodekss]. Pieejams: https://www.legislationline.org [aplūkots 01.03.2019.].

15 Додонов В. Н. Сравнительное уголовное право. Общая часть. Москва: Юрлитинформ, 2010, c. 59 .

16 Vērtējot labprātīgu radītā kaitējuma atlīdzināšanu vai novēršanu, par tādu atzīstams ne tikai fakts, ka vainīgais pats atlīdzinājis vai novērsis radīto kaitējumu (piemēram, salabojis sabojāto lietu), bet arī gadījumi, kad tas ir noticis pēc viṇa iniciatīvas - kad to pēc vainīgā pilnvarojuma (arī mutvārdu) izdara cita persona (sk.: Krastiņš U., Liholaja V. Krimināllikuma komentāri. Pirmā daḷa (I-VIII ${ }^{2}$ nodaḷa). Otrais papildinātais izdevums. Rīga: Tiesu namu aǵentūra, 2018, 201. lpp.; Augstākās tiesas Senāta Krimināllietu departamenta 19.03.2007. lēmums lietā Nr. SKK-194-2007. Pieejams: www.at.gov.lv [aplūkots 09.03.2019.]).

17 Krastiņš U., Liholaja V. 2018, 200.-201. lpp.

18 Augstākās tiesas 25.03.2014. lēmums lietā Nr. SKK-0163-14. Pieejams: https://manas.tiesas.lv/eTiesasMvc/nolemumi [aplūkots 10.03.2019.].

19 Stukāns J., Magone N. Tiesu prakse krimināllietās par noziedzīgiem nodarījumiem pret tikumību un dzimumneaizskaramību, kas izdarīti ar nepilngadīgo. Rīga, 2017, 47. lpp. Pieejams: http://at.gov.lv/lv/ judikatura/tiesu-prakses-apkopojumi/kriminaltiesibas/ [aplūkots 10.03.2019.].

20 Sk., piemēram: Kurzemes rajona tiesas 29.10.2018. spriedums lietā Nr. K69-1128-18/30. Pieejams: https://manas.tiesas.lv/eTiesasMvc/nolemumi [aplūkots 10.03.2019.]. 
Lai izvairītos no gadījumiem, kad saskaṇā ar Krimināllikuma 47. panta pirmās dal̦as 3. punktu par atbildību mīkstinošu atzīst daḷeju ar noziedzīgu nodarījumu radītā kaitējuma atlīdzināšanu, Krimināllikuma 47. panta pirmās daḷas 3. punktu varētu papildināt ar norādi, ka radītais kaitējums ir atlīdzināts vai novērsts pilnā apmērā jeb vainīgais labprātīgi pilnīgi atlìdzinājis cietušajam ar noziedzīgo nodarījumu radìto kaitējumu vai novērsis radìto kaitējumu. Salīdzinājumam jāuzsver, ka likumdevējs citur - Krimināllikuma 58. panta otrajā dalıāa ${ }^{21}$ - noteicis skaidru prasību pilnīgi novērst ar izdarīto noziedzīgo radīto kaitējumu vai atlīdzināt nodarīto zaudējumu.

Savukārt Krimināllikuma 47. panta pirmās dal̦as 1. punktā kā atbildību mīkstinošs apstāklis paredzēts: "Noziedzīgā nodarījuma izdarītājs pieteicies par vainīgu, vaḷsirdīgi atzinies un nožēlojis izdarīto.” Lai minēto apstākli varētu atzìt, nepieciešams konstatēt visu minēto elementu kopumu, uz ko skaidri norādīts attiecīgajā normā, kā arī pamatoti atzìts krimināltiesību doktrīnāâ un judikatūrā. ${ }^{23}$ Ja noziedzìgā nodarījuma izdarītājs nav pieteicies par vainīgu, ${ }^{24}$ taču savu vainu tam inkriminētā noziedzīgā nodarījumā pilnībā atzīst un izdarīto nožēlo, var lemt par šāda apstākḷa atzīšanu par atbildību mīkstinošu saskaṇā ar Krimināllikuma otro daļu. ${ }^{25}$ Iepriekš minētais ne vienmēr tiek ievērots, jo, pamatojoties uz Krimināllikuma 47. panta pirmās dal̦as 1. punktu, arī tiek atzìta tikai apsūdzētā vaḷsirdīga atzīšanās un izdarìtā nožēlošana. ${ }^{26}$

N̦emot vērā iepriekš minēto, apspriežams būtu jautājums par atsevišķa punkta nodalī̌̌anu Krimināllikuma 47. panta pirmajā dạ̦ā, ietverot kā atsevišķu atbildību mīkstinošu apstākli - noziedzīgā nodarījuma izdarīājs pieteicies par vainīgu, savukārt citus elementus - noziedzīgā nodarījuma izdarītājs vaḷsirdīgi atzinies un nožēlojis izdarīto - saglabājot vienā punktā.

Piemēram, Čehijas Republikas kriminālkodeksa ${ }^{27}$ (turpmāk - ČR KK) 41. pantā pie attiecīgajiem mīkstinošajiem apstākḷiem atsevišķos punktos nodalīta ziņošana par savu noziedzīgo nodarījumu (ČR KK 41. p. $k$ pkt.); nožēla par izdarīto nodarïjumu (ČR KK 41. p. $n$ pkt.).

${ }^{21}$ Krimināllikuma 58. panta otrajā daḷā noteikts: "Personu, kas izdarījusi kriminālpārkāpumu vai mazāk smagu noziegumu, izṇemot noziedzīgus nodarījumus, kuru rezultātā iestājusies cilvēka nāve, var atbrīvot no kriminālatbildības, ja ir izlīgums ar cietušo vai viṇa pārstāvi un persona pēdējā gada laikā nav tikusi atbrīvota no kriminālatbildības par tīša noziedzīga nodarījuma izdarǐšanu, noslēdzot izlīgumu, un pilnīgi novērsusi ar izdarīto noziedzīgo radīto kaitējumu vai atlīdzinājusi nodarīto zaudējumu."

22 Sk., piemēram: Krastiņš U., Liholaja V. 2018, 200. lpp.; Krastiņš U., Liholaja V., Niedre A. 2008, 386. lpp.

23 Sk., piemēram: Augstākās tiesas Senāta Krimināllietu departamenta 11.06.2008. lēmums lietā SKK313/2008. Pieejams: www.at.gov.lv [aplūkots 12.03.2019.].

${ }^{24}$ Pieteikšanās par vainīgu ir personas, kura izdarījusi noziedzīgu nodarījumu, ierašanās pirmstiesas izmeklēšanas iestādē, pie prokurora vai tiesā un paziṇošana par izdarīto noziedzīgo nodarījumu (Krastiņš U., Liholaja V., Niedre A. 2008, 386. lpp.).

25 Saskaņā ar Krimināllikuma 47. panta otro daḷu, nosakot sodu, par atbildību mīkstinošu var atzīt arī citu ar izdarīto noziedzīgo nodarījumu saistītu apstākli, kurš Krimināllikumā nav paredzēts. Piemēram, Kurzemes rajona tiesas 29.10.2018. spriedums lietā Nr. K69-1128-18/30, Rīgas pilsētas Vidzemes priekšpilsētas tiesas 17.04.2018. spriedums lietā Nr. K30-1612-18/32 Pieejams: https://manas.tiesas.lv/ eTiesasMvc/nolemumi [aplūkots 10.03.2019.]; Zemgales rajona tiesas 12.03.2019. spriedums lietā Nr. K73-0975-19/2. Pieejams: https://manas.tiesas.lv/eTiesasMvc/nolemumi [aplūkots 23.03.2019.].

${ }^{26}$ Rīgas pilsētas Vidzemes priekšpilsētas tiesas 05.04.2018. spriedums lietā Nr. K30-0493-18/5. Pieejams: https://manas.tiesas.lv/eTiesasMvc/nolemumi [aplūkots 10.03.2019.].

27 Criminal Code of the Czech Republic [Čehijas Republikas kriminālkodekss]. Pieejams: https://www. legislationline.org [aplūkots 16.03.2019.]. 
Ar 2018. gada 26. aprīla grozījumiem ${ }^{28}$ Krimināllikuma 48. panta pirmās daḷas 15. punktā kā atbildìbu pastiprinošs apstāklis var tikt atzìts gadījumos, ja noziedzīgs nodarījums, kas saistīts ar vardarbību vai vardarbības piedraudējumu, vai noziedzīgs nodarījums pret tikumību un dzimumneaizskaramību izdarîts pret personu, ar kuru noziedzīgā nodarījuma izdarìtājs ir vai ir bijis pastāvīgās intīmās attiecībās, aizstājot līdz tam ietverto formulējumu "neregistrētās laulāto attiecībās" ar - "pastāvīgās intīmās attiecībās". Latviešu valodā vārds "pastāvīgs" skaidrots kā 'nemainīgs, noturīgs, stabils, negrozīgs, nebeidzams, nemitīgs, nepārtraukts, biežs'; 'tāds, kas domāts ilgākam laikam'; 'tāds, kas dara ko ilgāku laiku, regulāri'.29 Vārds "intīms" skaidrots kā 'tuvs, dziḷi personisks'; 30 'tāds, kas attiecas uz cilvēka iekšējo pasauli, personisko dzīvi, dziḷi personisks'; 'tāds, kam raksturīga savstarpēja uzticība, sirsnība, simpātijas, l̦oti biedrisks, draudzīgs' ${ }^{31}$ Nemot vērā iepriekš minēto, ar pastāvīgām intīmām attiecībām būtu jāsaprot attiecības ar visai plašu tvērumu, ${ }^{32}$ piel̦aujot, ka "pastāvīgu intīmu attiecību" saturs konkrētā gadījumā tiks izvērsti analizēts praksē.

Krimināllikuma 50. pantā ietverti soda noteikšanas nosacijumi par vairāku noziedzīgu nodarījumu izdarī̌̌anu, tajā skaitā, ja sodu ar priekšrakstu par sodu nosaka prokurors. Krimināllikuma 50. panta otrajā ${ }^{33}$ un trešajā daḷă $\bar{a}^{34}$ noteikts, ka

${ }^{28}$ Grozijumi Krimināllikumā: LV likums. Pieņemts 26.04.2018. [17.03.2019. red.].

29 Sinonīmu vārdnīca. Rīga: Avots, 2001, 290., 683. lpp.; šḳirklis “pastāvīgs”. Interneta vārdnīca “Tēzaurs”. Pieejams: www.tezaurs.lv [aplūkots 17.03.2019.].

30 Sinonīmu vārdnīca, 151. lpp.

31 Šḳirklis “intīms”. Interneta vārdnīca “Tēzaurs”. Pieejams: www.tezaurs.lv [aplūkots 17.03.2019.].

32 Arī Ministru kabineta noteikumu "Noteikumi par Valsts probācijas dienesta informācijas sistēmā iekḷaujamās informācijas iekḷaušanas tiesisko pamatu, saturu, apjomu un apstrādes kārtību” 7.4. punktā ir norāde uz informācijas par intīmajām attiecībām iekḷaušanu informācijas sistēmā (Noteikumi par Valsts probācijas dienesta informācijas sistēmā iekḷaujamās informācijas iekḷaušanas tiesisko pamatu, saturu, apjomu un apstrādes kārtību: Ministru kabineta 13.11.2018. noteikumi Nr. 693 [17.03.2019.]. Jāatzīmē, ka Ministru kabineta noteikumu projekta "Noteikumi par Valsts probācijas dienesta informācijas sistēmā iekḷaujamās informācijas iekḷaušanas tiesisko pamatu, saturu, apjomu un apstrādes kārtību" sākotnējās ietekmes novērtējuma ziṇojumā (anotācijā) norādīts, ka termins "pastāvīgas intīmas attiecības" vislabāk raksturo nepieciešamo informāciju un tiek lietots Krimināllikuma 48. panta pirmās daḷas 15. punktā (sk. Ministru kabineta noteikumu projekta "Noteikumi par Valsts probācijas dienesta informācijas sistēmā iekḷaujamās informācijas iekḷaušanas tiesisko pamatu, saturu, apjomu un apstrādes kārtību” sākotnējās ietekmes novērtējuma ziṇojumu (anotāciju). Pieejams: https:// likumi.lv [aplūkots 17.03.2019.]).

33 Krimināllikuma 50. panta otrajā dạ̦ā noteikts: "Ja visi noziedzīgie nodarījumi, kas veido noziedzīgu nodarījumu kopību, ir kriminālpārkāpumi vai mazāk smagi noziegumi, galīgais sods nosakāms, ietverot vieglāko sodu smagākajā vai pilnīgi vai daḷeji saskaitot piespriestos sodus. Šādā gadījumā kopējais soda apmērs vai laiks drīkst pārsniegt maksimālo soda apmēru vai laiku, kāds paredzēts par smagāko no izdarītajiem noziedzīgajiem nodarījumiem, bet ne vairāk kā par pusi no maksimālā soda apmēra vai laika, kāds paredzēts par smagāko no izdarītajiem noziedzīgajiem nodarījumiem. Prokurors, sastādot priekšrakstu par sodu, kopējo soda apmēru vai laiku nedrīkst noteikt lielāku par maksimālo soda apmēru vai laiku, kāds paredzēts par smagāko no izdarītajiem noziedzīgajiem nodarījumiem.”

${ }^{34}$ Krimināllikuma 50. panta trešajā daḷā noteikts: "Ja vismaz viens noziedzīgais nodarījums, kas veido noziedzīgu nodarījumu kopību, ir smags vai sevišḳi smags noziegums, galīgais sods tiek noteikts, pilnīgi vai daḷejii saskaitot piespriestos sodus. Šādā gadījumā kopējais soda apmērs vai laiks drīkst pārsniegt maksimālo soda apmēru vai laiku, kāds paredzēts par smagāko no izdarītajiem noziedzīgajiem nodarỉjumiem, bet ne vairāk kā par pusi no maksimālā soda apmēra vai laika, kāds paredzēts par smagāko no izdarītajiem noziedzīgajiem nodarījumiem. Saskaitīto brīvības atņemšanas sodu (izņemot mūža ieslodzījumu) kopējais laiks nedrīkst pārsniegt 25 gadus, bet, ja izdarīts sevišķi smags noziegums, kura rezultātā iestājusies cietušā nāve, brīvības atṇemšanas soda kopējo laiku var noteikt arī uz visu mūžu (mūža ieslodzījums). Ja vismaz viens noziedzīgais nodarījums, kas veido noziedzīgu nodarījumu kopību, ir smags noziegums, par kuru paredzēts brīvības atņemšanas sods līdz pieciem gadiem, prokurors, 
prokurors, sastādot priekšrakstu par sodu, kopējo soda apmēru vai laiku nedrīkst noteikt lielāku par maksimālo soda apmēru vai laiku, kāds paredzēts par smagāko no izdarītajiem noziedzīgajiem nodarījumiem. Pēc autores domām, iepriekš minētā Krimināllikuma 50. pantā ietvertā norāde - kāds paredzèts par smagāko no izdarìtajiem noziedzīgajiem nodarījumiem - nav viennozīmīgi skaidrojama. Kà zināms, prokurors, sastādot priekšrakstu par sodu, saskaṇā ar Krimināllikuma normām ${ }^{35}$ kā pamatsodus drīkst noteikt tikai piespiedu darbu un naudas sodu, bet kā papildsodus - tiesību ierobežošanu un probācijas uzraudzību. Tā kā gan piespiedu darba, gan naudas soda ilgums un apmērs noteikts nevis Krimināllikuma Sevišķajā daḷā, bet gan Krimināllikuma Vispārīgās daḷas 40. un 41. pantā, tad paredzētais par smagāko noziedzīgo nodarījumu arī jāskata Krimināllikuma 40. un 41. pantā (ja naudas sods tiek piemērots nepilngadīgajiem, tad naudas sods piemērojams saskaṇā ar Krimināllikuma 65. panta ceturtajā daḷā noteikto - no vienas līdz piecdesmit Latvijas Republikā noteikto minimālo mēnešalgu apmērā). Saistībā ar piespiedu darbu un naudas sodu attiecīgi Krimināllikuma 40. un 41. pantā paredzēts, ka prokurors var noteikt ne vairāk par pusi no tā maksimālā apmēra vai ilguma, ko var noteikt tiesa saskaṇā ar Krimināllikuma 40. un 41. pantu (kā zināms, piemēram, piespiedu darbu - 140 stundas, kas attiecīgi ir noteiktā puse no 280 stundām).

Saistībā ar Krimināllikuma 50. pantā noteikto, kādu maksimālo apmēru vai laiku drīkst noteikt tiesa (ne vairāk par pusi no maksimālā soda apmēra vai laika, kāds paredzēts par smagāko no noziedzīgajiem nodarījumiem), piemērojot brīvības atņemšanu, skaidrojums tika veikts attiecīgā likumprojekta anotācijā, ${ }^{36}$ arī judikatūrā vērsta uzmanība uz piespiedu darba maksimālo ilgumu (420 stundas). ${ }^{37}$

Pēc autores domām, Krimināllikuma 50. pantā ietvertais regulējums būtu precizējams saistībā ar prokuroram noteikto, sastādot priekšrakstu par sodu, proti, vai "paredzēts" būtu attiecināms uz paredzēto kā maksimālo apmēru vai laiku prokuroram, sastādot priekšrakstu par sodu (piemēram, nosakot piespiedu darbu, jāṇem vērā Krimināllikuma 40. panta pirmajā daḷā regulētais, kas ir 140 stundas), vai šajā gadījumā tās būtu 280 stundas; tas, savukārt, nozīmē, ka par vismaz diviem noziedzīgiem nodarījumiem, nosakot kopējo soda apmēru vai laiku, tas jau būtu divas reizes vairāk nekā tad, ja sods tiek noteikts tikai par vienu noziedzīgu nodarījumu, kamēr tiesa saskaṇā ar Krimināllikuma 50. pantā noteikto nedrīkst noteikt vairāk par pusi no maksimālā soda apmēra vai laika, kāds paredzēts par smagāko no izdarītajiem noziedzīgajiem nodarījumiem.

sastādot priekšrakstu par sodu, kopējo soda apmēru vai laiku nedrīkst noteikt lielāku par maksimālo soda apmēru vai laiku, kāds paredzēts par smagāko no izdarītajiem noziedzīgajiem nodarījumiem."

35 Sk. Krimināllikuma 36. panta trešo dal̦u.

36 Sk.: Grozijumi Krimināllikumā: LV likums. Pieņemts 13.12.2012. [17.03.2019. red.]; Likumprojekta “Grozījumi Krimināllikumā” sākotnējās ietekmes novērtējuma ziṇojums (anotācija). Pieejams: titania. saeima.lv [aplūkots 17.03.2019.].

37 Augstākās tiesas 09.01.2015. lēmums lietā SKK-J13/2015. Pieejams: www.at.gov.lv/lv/judikatura/judikaturas-nolemumu-arhivs/kriminallietu-departaments [aplūkots 17.03.2019.]. 


\section{Kopsavilkums}

1. Latvijas Republikas Satversmes 90. pantam ir ìpaša nozīme krimināltiesību kontekstā, un kopsakarā ar Latvijas Republikas Satversmes 92. pantu tas sevišķi garantē tiesības uz krimināltiesību normu skaidrību un paredzamību.

2. Lai izvairītos no gadījumiem, kad saskaṇā ar Krimināllikuma 47. panta pirmās daḷas 3. punktu par atbildību mīkstinošu atzīst daḷeju ar noziedzīgu nodarījumu radītā kaitējuma atlīdzināšanu, Krimināllikuma 47. panta pirmās daḷas 3. punktu varētu papildināt ar norādi, ka radītais kaitējums ir atlīdzināts vai novērsts pilnā apmērā jeb vainīgais labprātīgi pilnīgi atlīdzinājis cietušajam ar noziedzīgo nodarījumu radìto kaitējumu vai novērsis radīto kaitējumu. Salīdzinājumam jāuzsver, ka likumdevējs citur - Krimināllikuma 58. panta otrajā dal̦āi ${ }^{38}$ - noteicis skaidru prasību pilnīgi novērst ar izdarīto noziedzīgo radìto kaitējumu vai atlīdzināt nodarìto zaudējumu.

3. Apspriežams būtu jautājums par atsevišķa punkta nodalīšanu Krimināllikuma 47. panta pirmajā daḷā, ietverot kā atsevišksu atbildību mīkstinošu apstākli, ja noziedzīgā nodarījuma izdarītājs pieteicies par vainīgu, savukārt citus elementus - noziedzīgā nodarījuma izdarītājs val̦sirdīgi atzinies un nožēlojis izdarīto saglabājot vienā punktā.

4. Krimināllikuma 50. pantā ietvertais regulējums būtu precizējams saistībā ar prokuroram noteikto, sastādot priekšrakstu par sodu, proti, vai "paredzēts" būtu attiecināms uz paredzēto kā maksimālo apmēru vai laiku prokuroram, sastādot priekšrakstu par sodu (piemēram, nosakot piespiedu darbu, jāṇem vērā Krimināllikuma 40. panta pirmajā daḷā regulētais, kas ir 140 stundas), vai šajā gadījumā tās būtu 280 stundas; tas, savukārt, nozīmē, ka par vismaz diviem noziedzīgiem nodarījumiem, nosakot kopējo soda apmēru vai laiku, tas jau būtu divas reizes vairāk nekā tad, ja sods tiek noteikts tikai par vienu noziedzīgu nodarījumu, kamēr tiesa saskaṇā ar Krimināllikuma 50. pantā noteikto nedrīkst noteikt vairāk par pusi no maksimālā soda apmēra vai laika, kāds paredzēts par smagāko no izdarītajiem noziedzīgajiem nodarījumiem.

${ }^{38}$ Krimināllikuma 58. panta otrajā daḷā noteikts: "Personu, kas izdarījusi kriminālpārkāpumu vai mazāk smagu noziegumu, izṇemot noziedzīgus nodarījumus, kuru rezultātā iestājusies cilvēka nāve, var atbrīvot no kriminālatbildības, ja ir izlīgums ar cietušo vai viṇa pārstāvi un persona pēdējā gada laikā nav tikusi atbrīvota no kriminālatbildības par tīša noziedzīga nodarījuma izdarīšanu, noslēdzot izlīgumu, un pilnīgi novērsusi ar izdarīto noziedzīgo radīto kaitējumu vai atlīdzinājusi nodarīto zaudējumu." 